\title{
Strategi Marketing Mix Dalam Meningkatkan Usaha Percetakan Pada CV. Tinta Kaili Dalam Perspektif Ekonomi Islam
}

\author{
Warni Lestari ${ }^{1 *}$ Sitti Musyahidah ${ }^{2}$, Rabaniah Istiqamah ${ }^{3}$ \\ ${ }^{1}$ Jurusan Ekonomi Syariah, Fakultas Ekonomi dan Bisnis Islam, IAIN Palu \\ 2 Jurusan Ekonomi Syariah, Fakultas Ekonomi dan Bisnis Islam, IAIN Palu \\ ${ }^{3}$ Jurusan Ekonomi Syariah, Fakultas Ekonomi dan Bisnis Islam, IAIN Palu
}

ABSTRAK

Penelitian ini bertujuan untuk mengetahui apakah Strategi marketing mix yang terdiri dari produk (product), harga (price), tempat (place), promosi (promotion) telah terealisasi, dimana setiap konsumen mempunyai perbedaan serta alasan mengkonsumsi barang dan jasa. Alasan tersebut membuat perusahaan harus memenuhi kebutuhan dan keinginan pelanggan, yang selanjutnya menciptakan kesadaran dan ketertarikan pelanggan kepada produk dan jasa yang bersangkutan. Metode penelitian dilakukan yaitu deskripsi (description) adalah salah satu jenis metode penelitian yang berusaha menggambarkan dan menginterpretasi objek sesuai dengan apaadanya. Hasil penelitian yang dilakukan penulis bahwasannya penerapan marketing mix yang ada di percetakan CV. Tinta Kaili sangat berpengaruh terhadap meningkatnya usaha ini hingga berkembangnya dan maju, tetap eksis hinga saat ini dilihat dari usaha yang ada di perusahaan itu sendiri. Dengan adanya penerapan nilai - nilai Islami dalam menjalankan usaha yang dirintis serta tak luput perhatian seorang pemimpin dan kerjasama tim yang baik dalam bekerja. Perspektif ekonomi Islam dalam memasarkan produknya sangat memperhatikan etika - etika bisnis. Dalam ekonomi Islam juga menerapkan pemasaran atau promosi untuk menawarkan, menginformasikan, menjual produk atau jasa di pasar. Karena dengan memasarkan atau mempromosikan masyarakat akan mengetahui keberadaan produk atau jasa,
INFORMASI ARTIKEL

\section{Kata kunci:}

Marketing mix, pemasaran, usaha percetakan, Tinta Kaili, ekonomi Islam 


\section{PENDAHULUAN}

Banyak orang yang berkeinginan untuk melakukan bisnis, baik mahasiswa, ibu rumah tangga hingga karyawan dan modal sering menjadi alasan utama batalnya niat untuk memulai usaha. Padahal dalam merintis sebuah usaha tidak sepenuhnya bergantung pada aspek permodalan karena pada kenyataannya banyak orang memiliki modal namun bingung untuk menetukan investasi yang akan dijalani dalam dunia kewirausahaan. ${ }^{1}$

Kewirausahaan adalah suatu ilmu yang mengkaji tentang pengembangan dan pembangunan semangat kreativitas serta berani menaggung risiko terhadap pekerjaan yang dilakukan demi mewujudkan hasil karya tersebut. Keberanian mengambil resiko sudah menjadi milik seorang wirausahawan karena ia dituntut untuk berani dan siap jika usaha yang dilakukan tersebut belum memiliki nilai perhatian di pasar. ${ }^{2}$ Peter F. Drucker dalam Kasmir mengatakan bahwa kewirausahaan merupakan kemampuan dalam menciptakan sesuatu yang baru dan berbeda. ${ }^{3}$

Olehnya modal bukanlah jadi penghambat seseorang dapat menjalankan sebuah usaha, dengan membangun bisnis

\footnotetext{
${ }^{1}$ Irham Fahmi, Kewirausahaan: Teori, Kasus dan Solusi. (Bandung: Alfabeta, 2014) 1

${ }^{2}$ Ibid. 2

${ }^{3}$ Kasmir, Kewirausahaan (Jakarta, Raja Grafindo Persada, 2006). 17
}

keberanianlah yang menjadi dorongan seorang dalam bertindak atau actionuntuk menjadi wirausahaan sukses.

Istilah bisnis sendiri diambil dari kata business (bahasa inggris) yang berarti kegiatan usaha (perusahaan). Secara luas kegiatan bisnis diartikan sebagai kegiatan usaha yang dijalankan oleh orang atau badan usaha secara teratur dan terus menerus, yaitu berupa kegiatan mengadakan barang-barang atau jasa maupun fasilitasfasilitas untuk diperjualbelikan, atau disewakan dengan tujuan mendapatkan keuntungan. Dengan demikian kegiatan usaha dalam bidang bisnis dapat dibedakan dalam tiga bidang menurut Richard Burton Simatupang dalam Zaeni Asyhadie, sebagai berikut:

Usaha dalam arti kegiatan perdagangan commerce, yaitu keseluruhan kegiatan jual beli yang dilakukan oleh orangorang atau badan-badan, baik di dalam maupun di luar negeri untuk memeperolah keuntungan. Contoh kegiatan ini adalah menjadi dealer, agen, grosir, toko dan lain sebagainya.

Seseorang yang telah memutuskan untuk menjadi pelaku usaha meskipun dalam skala kecil dapat disebut wirausahawan. Sebagai seorang wirausahawan maka ia perlu mengembangkan jiwa kewirausahaan. Dalam praktik seorang wirausahawan terjadi dengan sendirinya dan kemudian sukses; untuk yang demikian ini disebut mereka memiliki bakat.Pengertian wirausaha 
menurut The American Heritage dictionary,wirausahawan didefinisikan dengan seseorang yang mengorganisasikan, mengopreasikan dan memperhitungkan resiko untuk sebuah usaha yang mendatangkan laba. ${ }^{4}$ Dalam pengetian ini terdapat kata 'mengorganisasikan'seorang pelaku usaha dalam skala kecil sekalipun menjalankan kegiatannya akan selalu menggunakan berbagai sumber daya manusia, finansial, peralatan fisik, informasi dan waktu. Dengan demikian seorang pelaku usaha telah melakukan pengorganisasian terhadap sumber daya yang dimilikinya dalam ruang dimensi yang terbatas dan berusaha mengoperasikan sebagai kegiatan usaha guna mencapai laba. ${ }^{5}$

Dalam melakukan bisnis usaha seseorang mempunyai tujuan untuk memperolah laba, namun tujuannya tidak semata-mata karena laba.Islam mewajibkan setiap muslim khususnya yang memiliki tanggungan untuk bekerja. Bekerja merupakan salah satu sebab pokok yang memungkinkan manusia memiliki harta kekayaan. ${ }^{6}$ Dengan berusaha mencari nafkah, Allah swt telahmelapangkan bumi

\footnotetext{
${ }^{4}$ Mulyadi Nitisusastro, Kewirausahan \& Manajemen Usaha Kecil. (Bandung: Alfabeta, 2009) 26

${ }^{5}$ Ibid, 27

${ }^{6}$ Muhammad Ismail Yusant dan Muhammad Karebet Wijajakusuma, Mengagas Bisnis Islam. ( Jakarta: Gema Insane Press, 2002) cet 117
}

serta menyediakan berbagai fasilitas yang dapat dimanfaatkan manusia mencari rezeki.

Pengusaha dalam pandangan etika islam bukan sekedar mencari keuntungan, melainkan juga keberkahan, yaitu kemantapan dari usaha itu dengan memperolah keuntungan yang wajar dan diridhoi oleh Allah swt. Ini berarti harus diraih oleh seorang pedagang dalam melakukan bisnis tidak sebatas keuntungan materiil (bendawi), tetapi yang paling penting lagi adalah keuntungan immaterial (spiritual). ${ }^{7}$

Berkembangnya zaman yang semakin maju dan didukung oleh perkembangnya teknologi yang mutakhir, kehidupan dunia usaha mengalami persaingan yang semakin ketat agar dapat bisa bertahan dan terus berkembang demi mendukung tujuan jangka panjang bisnis usahanya. Dengan mengandalkan kemajuan tekonologi tersebut, banyak orang yang melirik peluang usaha percetakan. Dimana saat ini salah satu usaha di Kota Palu dapat dikatakan sebagai bisnis yang tidak pernah surut, yaitu usaha percetakan. ${ }^{8}$ Usaha percetakan adalah usaha memproses gambar atau kalimat ke dalam kertas maupun kain

\footnotetext{
${ }^{7}$ Muhammad Djakfar, Etika Bisnis Islami Tataran Teoritis dan Praktis, (Jakarta: Selemba Empat, 2006), h.86

${ }^{8}$ Rizka Fitriani Putri “Analisis Pengadaan Persediaan Bahan Baku Kertas Dalam Menunjang Proses Produksi pada CV. Sumber Warna Bandung". Blogspot.repository.widyatama.ac.id. Di unduh 24 Desember 2015
} 
sehingga konsumen mengetahui maksud yang disampaikan. Usaha ini membutuhkan berbagai proses dari segi bentuk dan pengaturan tata letak gambar, kata-kata, serta warna, untuk memberikan kepuasan kepada pelanggan sehingga pelanggan akandatang untuk kembali menggunakan jasa tersebut. Usaha percetakan yang menggunakan border computer dan mesinmesin digital printing, yang mana saat ini mulai diperhitungkan keberadaannya yang semakain pesat dan usaha tersebut memiliki banyak peminatnya, dengan berbagai jenis tawaran print digital lainnya, yang menjadi kebutuhan masyarakat pada umumnya. Dalam memproses cetakan, dibutuhkan tinta cetak, flat, mesin cetak, mesin potong dan karyawan. Bisnis percetakan dapat dimulai dengan mencetak keperluan anak sekolah, keperluan kantor, keperluan instansi, keperluan dari departemen-departemen sehingga dapat melakukan penawaran kesekolah, kantor maupun kedepartemen. Hubungan baik dengan berbagai pihak serta menjaga kualitas produk sangat diperlukan untuk mendapatkan pesanan dalam jumlah besar.

Percetakan CV. Tinta Kaili telah ada sejak 1996, yang saat pertama kali berdiri dipelopori oleh 3 orang mahasiswa awal mulanya memulai usaha sablon kecilkecilan. Seiring berjalannya waktu usaha sablon yang mereka kerjakan yang mulanya menggunakan cara tradisional hasil cetakannya pun sangat jauh dari kata sempurna. Berkembangan Kota Palu yang saat itu menjamur iklan-iklan publikasi spanduk terpampang di jalan kota memunculkan ide mendirikan perusahaan yang berbadan hukum pada tahun 2004 .

Ketatnya persaingan usaha membuat pengusaha menciptakan strategi untuk memasarkan produk dan jasa yang mereka miliki dan menawarkan kepada masyarakat.Seiring dengan sejarah manusia dalam memenuhi kebutuhanya, ada pihak yang meminta dan ada yang menawarkan.Pemasaran menarik perhatian yang sangat besar baik dari perusahaan agar tetap eksis dan bertahan di pasar dengan produk barang dan jasa yang diminati dikalangan masyarakat.

\section{TINJAUAN PUSTAKA}

\subsection{Konsep Pemasaran}

Manajemen pemasaran adalah kegiatan manajemen berdasarkan fungsinya yang pada intinya untuk mengidentifikasi sesungguhnya apa yang dibutuhkan konsumen, maka pebisnis perlu melakukan riset pemasaran, diantaranya survei tentang keinginan konsumen sehingga pebisnis bisa mendapatkan informasi mengenai apa sesungguhnya dibutuhkan oleh konsumen ini 
kemudian diteruskan ke bagian produksi untuk dapat diwujudkan. Setelah output produk terwujud terwujud, makan manajemen pemasaran kemudian juga melakukan kegiatan dalam proses penyampaian produk kepada konsumen. ${ }^{9}$

Definisi Pemasaran menurut American Marketing Association, menyatakan bahwa pemasaran adalah hasil prestasi kerja kegiatan usaha yang berkaitan dengan mengalirnya barang dan jasa dari produsen sampai ke konsumen. Disamping itu terdapat penafsiran yang lebih luas, yang menyatakan pemasaran merupakan proses kegiatan yang mulai jauh sebelum barangbarang / bahan-bahan masuk dalam proses produksi. Dalam hal ini banyak keputusan pemasaran yang harus dibuat jauh sebelum produk itu dihasilkan, seperti keputusan mengenai produk yang dibuat, pasarnya, harga, dan promosinya. ${ }^{10}$

Pengertian lain dari pemasaran adalah salah satu kegiatan pokok yang perlu dilakukan oleh perusahaan baik itu perusahaan barang atau jasa dalam upaya untuk mempertahankan kelangsungan hidup usahanya. Hal tersebut disebabkan karena pemasaran merupakan salah satu kegiatan perusahaan, di mana secara langsung

${ }^{9}$ Ernie Tisnawati Sule \& Kurniawan Saefullah, Pengantar Manajemen (Jakarta: Kencana, 2005) 14

${ }^{10}$ Sofjan Assauri, Manajemen Pemasaran, (Jakarta: RajaGrafindo Persada,2009) 3 berhubungan dengan konsumen. Maka kegiatan pemasaran dapat diartikan sebagai kegiatan manusia yang berlangsung dalam kaitannya dengan pasar. Kotler mengemukakan definisi pemasaran berarti bekerja dengan pasar sasaran untuk mewujudkan pertukaran yang potensial dengan maksud memuaskan kebutuhan dan keinginan manusia. Sehingga dapat dikatakan bahwa keberhasilan pemasaran merupakan kunci kesuksesan dari suatu perusahaan. ${ }^{11}$

Pemasaran erat kaitannya dengan kegitan yang diperlukan untuk mengantar barang-barang mulai dari pintu pagar produsen sampai ke dalam batas-batas jangkauan konsumen, atau pengertian yang lain, menurut pakar pemasaran, yaitu William J. Stantom, Etzel \& Walker; marketing is a total system business designed to plan, price, promote and distribute want satisfying products to target marketto achieve organizational objective (pemasaran adalah suatu system total dari kegiatan bisnis yang dirancang untuk merencanakan, menetukan harga, promosi, dan mendistribusikan barang-barang yang

\footnotetext{
${ }^{11}$ Dirman, “Manajemen,” Blog Dirman, http://skripsi-manajemen. blogspot.co.id/search llabel/Materi\%20Skripsi( 23 november 2015)
} 
dapat memuaskan keinginan dan mencapai pasar sasaran serta tujuan perusahaan).$^{12}$

Sedangkan menurut Philip Kotler(marketing is a social and manajerial process by which individuals and groups obtain what they need and what throught creating, offering and exchanging products of value of which other (pemasaran adalah proses social dan manjerial dengan mana sesorang atau kelompok memperoleh apa yang mereka butuhkan dan inginkan melalui penciptaan dan pertukaran produk dan nilai).

Pemasaran hendaknya memberi sumbangan pada perluasan dan pemuasan kebutuhan dan keinginan manusia. Pemasaran haruslah merupakan sarana dari organisasi-organisasi untuk mengetahui kebutuhan manusia yang tidak terpenuhi. Barulah menjadi peluang usaha, menciptakan pemenuhan kebutuhan yang digunakan itu sendiri. Mempertahankan untuk tetap hidup dan memperoleh keuntungan sangat tergantung dari kemampuan untuk menciptakan manusia yang selalu berubah.

Dewasa ini hadir berbagai bentuk dari ukuran organisasi, ada yang merupakan milik umum dan perorangan. Motivasi untuk membentuk organisasi adakalanya mewujudkan perbuatan yang besar untuk mendapatkan keuntungan yang besar, atau

12 Danang Sunyoto, Strategi Pemasaran (Jakarta: Buku Seru, 2015), 1 untuk memenuhi kebutuhan yang penting. untu $\mathrm{k}$ mencapai tujuan organisasi harus menhimpun dana, mencari tenaga kerja, penyediaan fasilitas produksi atau jasa, dan pasar bagi produknya. ${ }^{13}$

Setiap perusahaan mempunyai tujuan untuk dapat tetap hidup dan berkembang, tujuan tersebut hanya dapat dicapai melalui usaha mempertahakan dan meningkatkan tingkat keuntungan dan laba perusahaan. Usaha ini dapat dilakukan apabila perusahaan dapat memepertahankan dan meningkatkan penjualannya, melalui usaha mencari dan membina langganan, serta usaha menguasai pasar.

Tujuan pemasaran hanya dapat dicapai apabila bagian pemasaran perusahaan melakukan strategi yang baik untuk dapat menggunakan kesempatan atau peluang yang ada dlam pemasaran, sehingga posisi atau kedudukan perusahaan di pasar dipertahankan dan sekaligus ditingkatkan. Seperti diketahui dunia usaha bersifat dinamis, yang diwarnai dengan adanya perubahan dari waktu ke waktu.

Oleh karena itu strategi pemasaran mempunyai pernana penting untuk keberhasilan usaha perusahaan umumnya dan bidang pemasaran khususnya. Strategi pemasaran yang ditetapkan harus ditinjau dan dikembangkan sesuai dengan

13 M. mursid, Manajemen Pemasaran, (Jakarta:Bumi Aksara, 2014 ) 4 
perkembangan pasar dan lingkungan pasar tersebut. Strategi pemasaran harus mempunyai gambaran yang jelas dan terarah tentang apa yang dilakukan perusahaan dalam mengunakan setiap kesempatan atau peluang pada beberapa pasar sasaran. Untuk mencapai keberhasilan kegiatan pemasaran yang dilakuakan oleh perusahaan, yaitu pasar yang dituju dan acuan pemasaran yang dijalankan untuk sasaran pasar tersebut. ${ }^{14}$

Pengusaha yang mengenal bahwa pemasaran merupakan faktor penting untuk mencapai sukses bagi perusahaannya akan mengetahui cara dan falsafah yang didalamnya yaitu konsep pemasaran.

Konsep pemasaran adalah sebuah filsafat bisnis yang mengatakan bahwa kepuasan dan keinginan dari konsumen adalah dasar kebenaran social dan ekonomi sebuah perusahaan. ${ }^{15}$ Apabila seorang pengusaha sudah mengetahui bahwa pemasaran merupakan factor yang sangat pentinyang dalam hal memasarkan produknya maka pengusaha tersebut akan berusaha semaksimal mungkin dalam mensukseskan dan melaksanakan cara baru yang terlibat dalam kegiatan pemasaran yang disebut konsep pemasaran.

Konsep pemasaran adalah suatu falsafah manajemen dalam bidang

\footnotetext{
${ }^{14}$ Ibid, 168

${ }^{15}$ Muhammad Tohir, Pengertian Konsep Pemasaran, http://www.lebahmaster.com, (12 Juli 2015)
}

manajemen yang berorientasi kepada kebutuhan dan keninginan konsumen dengan didukung oleh kegiatan pemasaran terpadu yang diarahkan untuk memberikan kepuasan konsumen sebagai kunci keberhasilan organisasi mencapai tujuan yang telah ditetapkan. Jadi konsep pemasaran merupakan orientasi perusahaan yang menekankan bahwa tugas pokok perusahaan adalah menentukan kebutuhan dan keinginan tersebut sehingga di capai tingkat kepuasan langganan melebihi dari kepuasan yang diberikan oleh para saingan. ${ }^{16}$

Konsep pemasaran bertujuan untuk memberikan kepuasan terhadap kebutuhan dan keinginan konsumen dengan mendapatkan sejumlah laba, maka seluruh kegiatan dalam perusahaan yang menganut konsep pemasaran harus diarahkan. Untuk memnuhi tujuan tersebut, kegiatan ini meliputi perusahaan, pemasaran, produksi, dan kegiatan lain.

Adapun konsep-konsep-konsep inti pemasaran meliputi : kebutuhan, keinginan, permintaan, produksi, nilai dan kepuasan, kepuasan, pertukaran, transaksi, dan hubungan pasar, pemasaran dan pasar. ${ }^{17}$

Pada hakikatnya konsep pemasaran menekankan orientasi pada kebutuhan dan

\footnotetext{
${ }^{16}$ Sofyan Assauri, M.B.A. Manajemen Pemasaran, Ed 1-8 (Jakarta : PT. Raja Grafindo Persada, 2007),h. 81

${ }^{17}$ Abdul Majid, "Konsep Pemasaran," Majidbscz. Wordpress.com, 2008, (15 Juli 2015)
} 
keinginan konsumen yang didukung oleh keinginan konsumen yang didukung oleh kegiatan pemasaran yang terpadu, yang ditunjukan untuk keberhasilan mencapai tujuan perusahaan. Dengan demikian ada empat unsur pokok yang terdapat dalam konsep pemasaran, yaitu orientasi pada konsumeng (kebutuhan dan keinginan konsumen), kegiatan pemasaran yang terpadu, kepuasan konsumen/pelanggan dan tujuan perusahaan jangka panjang.

Konsep pemasaran ini sering dicampur adukkan atau dikaburkan dengan istilah konsep penjualan. Konsep penjulan menekankan orientasi pada produk yang di hasilkan untuk dijual yang didukung dengan kegiatan penjualan dan promosi, sehingga tujuan perusahaan jangka pendek dapat dicapai melalui pencapaian target penjualan.

Dalam buku kewirausahaan, Kashmir menjelaskan bahwa pemasaran dapat bermakna untuk memenuhi keinginan dan kebutuhan konsumen melalui penciptaan produk baik barang maupun jasa. ${ }^{18}$

Definisi pemasaran menurut Stanton dalam bukunya, Fundamental of Marketing, terjemahan Y. Lamanto, adalah suatu system keseluruhan dari kegiatan-kegiatan bisnis yang ditujukan untuk merencanakan, menentukan harga, kebutuhan, baik kepada

\footnotetext{
${ }^{18}$ Kashmir, Kewirausahaan, (Jakarta: Raja Grafindo Persada, 1999), h. 32
}

pembeli yang ada maupun pembeli potensial. ${ }^{19}$

Pada dasarnya pemasaran barang mencakup perpindahan atau aliran dari dua hal, yaitu aliran fisik barang itu sendiri dan aliran kegaitan transaksi untuk barang tersebut. Aliran kegiatan transaksi merupakan rangkaian kegiatan transaksi, mulai dari penjual produsen sampai kepada pembeli konsumen akhir.

Pengertian pemasaran dibedakan menjadi dua yaitu:

a. Macro marketing, yaitu membahas tentang akitivitas dan system pertukaran dilihat dari perspektif msyarakat luas.

b. Micro marketing, yang membahas tentang akitfitas dan system pertukaran dilihat dari perspektif hubungan antara perusahaan sebagai produsen dan konesumen.

Peranan lembaga pemasaran sangat tetgantung dari system pasar yang berlaku dan karakteristik aliran barang yang diapasarkan. Oleh karena itu dikenal istilah "Saluran pemasaran" atau marketing chanel. Dalam bukunya J. Winardi, konsep pemasaran diawali dengan baik kemudian pusat perhatian diletakkan pada kebutuhan para pelanggan setelah mana dilaksanakan koordinasi semua kegiatan yang akan

\footnotetext{
${ }^{19}$ Satanton, J.William, Fundamental of Marketing, terjemahan Y. Lamanto. (Jakarta : PT. Erlangga, 1996), h. 54
} 
mempengaruhi para pelanggan dan dicapai laba melalui upaya memuaskan para pelanggan. ${ }^{20}$

Definisi konsep pemasaran adalah orientasi manajamen yang menekankan bahwa kunci pencapaian tujuan organisasi terdiri dari kemampuan perusahaan tersebut memenuhinya dengan kepuasan yang diinginkan secara efektif dan efisien dari pesaing. ${ }^{21}$

Konsep pemasaran adalah sebuah falsafah bisnis yang menyatakan bahwa pemuasan kebutuhan konsumen merupakan syarat ekonomi dan social bagi kelangsungan hidup perusahaan.

Sebagai falsafah bisnis, konsep pemasaran dibuat dengan menggunakan tiga factor dasar yaitu :

1. Seluruh perencanaan dan kegiatan perusahaan berorientasi pada konsumen/ pasar. Pada dasaranya perusahaan yang ingin mempraktekkan orientasi konsumen harus

a. Menentukan kebutuhan pokok dan pembeli yang akan dilayani dan dipenuhi.

b. Memilih kelompok pembeli tertentu sebagai sasaran dalam penjualan

c. Menentukan produk dan program pemasarann

\footnotetext{
${ }^{20} \mathrm{~J}$. Winardi, Enterpreneur dan entrepreneurship, Cet II; (Jakarta : Peradana Media, 2005), h. 5

${ }^{21}$ Sofyan Assauri, Manajemen Produksi (Jakarta: Rajawali Press, 1998 ). 72
}

d. Melaksanakan dan menentukan strategi yang paling baik menitik beratkan pada mutu yang lebih tinggi, harga yang murah dengan model yang menarik

2. Volume penjualan yang menguntungkan harus menjadi tujuan perusahaan. Laba dapat diperoleh dengan melalui pemuasan konsumen, dengan laba tersebut, maka perusahaan dapat tumbuh, berkembang dan dapat mempertahankan kelangsungan hidup usahanya.

3. Seluruh pemasaran dalam perusahaan harus dikordinasikan dan diintegrasikan secara organisasi, dalam perusahaan, hal ini perlu dilakukan untuk memberikan kepuasan konsumen, juga perlu dihindari adanya pertentangan di dalam perusahaan maupun antar perusahaan dengan pasar.

Perusahaan harus menetapakan konsep pemasaran dalam praktik agar keuntungan yang terkandung di dalamnya dapat direalisasikan dan dalam pelaksanaannya diperlukan manajemen pemasaran. ${ }^{22}$

Manajemen pemasaran adalah penganalisaan, perencanaan, pelaksanaan dan pengawasan program-program yang ditunjukkan untuk mengadakan pertukaran dengan pasar yang dituju dengan maksud mencapai tujuan organisasi. Hal ini sangat bergantung pada penawaran orang dalam memenuhi kebutuhan dan keinginan pasar

22 Basu Swasta, Manajemen Pemasaran Modern. (Jakarta : Liberty,2000) 17 
tersebut serta dalam menentukan harga, mengadakan komunikasi dan distribusi yang efektif untuk memberitahu, mendorong serta melayani pasar. ${ }^{23}$

\subsection{Marketing Mix}

Marketing mix merupakan strategi kombinasi yang dilakukan oleh berbagai perusahaan dalam bidang pemasaran. hampir semua perusahaan melakukan strategi ini guna mencapai tujuan pemasarannya, apalagi dalam kondisi persaingan yang demikian ketat saat ini. ${ }^{24}$ Dalam pemasaran mengenal dengan teori marketing mix lebih mengedepankan pembauran (gabungan) teori pemasaran atau marketing pada umumnya, dalam memasarkan produk (barang) maupun jasa.

Pengertian marketing mix adalah menjalankan kegiatan pemasaran yang dilakukan secara terpadu. Artinya kegiatan ini dilakukan secara bersama (gabungan) di antara elemen-elemen yang ada dalam marketing mix itu sendiri. Karena dalam konsepnya, setiap elemen pemasaran tidak dapat berjalan sendiri-sendiri, tanpa didukung oleh elemen lainnya. Penggunaan marketing mix dalam dunia bisnis, tentunya dilakukan dengan menggunakan konsep-

\footnotetext{
${ }^{23}$ Philip Kotler, Manajemen Pemasaran. (Jakarta: PT. Rosdakarya 1993). 20

24 Kasmir, Pemasaran Bank, ed revisi (Jakarta, kencana, 2004). 119
}

konsep yang sesuai kebutuhan masingmasing prusahaan.

Dalam praktiknya, konsep marketing mix terdiri dari marketing mix untuk barang dan marketing mix untuk jasa. Khusus untuk produk yang berbentuk jasa, diperlukan konsep yang sedikit berbeda dengan produk barang. ${ }^{25}$ Kotler menyebutkan konsep bauran pemasaran (marketing mix) terdiri dari empat 4 elemen, yaitu: Product (produk) Price (harga) Place (tempat/saluran distribusi); dan Promotion (Promisi). ${ }^{26}$

\section{a. Product (Produk)}

Produk adalah segala sesuatu yang bisa ditawarkan kepasar untuk diperhatikan, dimiliki, digunakan, atau dikonsumsi sehingga bisa memuaskan kebutuhan dan keinginan. Produk tersebut mencakup obyek, fisik, orang tempat, organisasi, dan ide, jasa ini adalah segala aktivitas atau manfaat yang ditawarkan untuk dijual oleh salah satu pihak secara esencial tidak berwujud dan tidak menghasilkan kepemilikan atas apapun. ${ }^{27}$

b. Price (Harga)

Harga adalah sejumlah uang yang dibutuhkan konsumen untuk mendapatkan

\footnotetext{
${ }^{25}$ Rizal, “Marketing Mix," Rizal http://pengertian-

isp.blogspot.com/2015/05/pengertian-marketing-mixmarketing-pemasaran.html(on-line) diakses pada tanggal 23 November 15

${ }^{26}$ Kasmir, Manajeman Perbankan, (Jakarta: RajaGrafindo Persada, 2003) 192

${ }^{27}$ Philip Kotler dan Gary Amstrong, Dasardasar Pemasaran, Terjemahan oleh Alexander Sindoro, (Jakarta : Indeks Gramedia, 2003), 8
} 
suatu produk guna memenuhi kebutuhan dan keinginan yang belum terpenuhi. Kotler berpendapat bahwa harga adalah satusatunya unsur bauran pemasaran yang menghasilkan pendapatan, unsur lainnya menimbulkan biaya. Harga juga merupakan salah satu unsur bauran pemasaran paling fleksibel, harga mudah diubah dengan cepat, tidak seperti tampilan produk dan perjanjian distribusi.

\section{c. Place (Lokasi)}

Lokasi merupakan tempat melayani konsumen, dapat pula diartikan sebagai tempat untuk memajangkan barang-barang dagangannya.Konsumen dapat melihat langsung barang yang diproduksi atau dijual baik jenis jumlah maupun harganya.

Tempat menunjukkan berbagai kegiatan yang dilakukan oleh perusahan untuk menjadikan produk dapat diperoleh dan tersedia bagi konsumen sasaran. Produsen harus mengatur seluruh distribusi yang tepat, dengan mengecek persediaan dan mengatur pengangkutan dan penyimpanan produk.

\section{d. Promotion (Promosi)}

Promosi merupakan berbagai kegiatan yang dilakukan perusahaan dengan tujuan utama untuk menginformasikan, membujuk, mempengaruhi dan mengingatkan konsumen agar membeli produk yang dihasilkan. Untuk melaksanakan kegiatan promosi produk perusahaan secara keseluruhan khususnya kegiatan penjualan, maka produsen harus memilih dan menetapkan secara seksama elemen-elemen dalam bauran promosi (promotion mix) yang terdiri dari 5 (lima) yaitu periklanan, promosi, hubungan masyarakat, penjualan pribadi, dan pemasaran langsung.

Dalam melakukan promosi ada hal-hal yang perlu diperhatikan dalam pemilihan bauran promosi yang terdiri atas iklan (advertising), penjualan perseorangan (personal selling), promosi penjualan (sales promotion), hubungan masyarakat (public relation), informasi dari mulut ke mulut (words of mouth) dan surat pemberitahuan langsung (direct mail). ${ }^{28}$

Keempat strategi tersebut di atas saling mempengaruhi, sehingga semuanya penting sebagai satu kesatuan strategi, yaitu strategi acuan/bauran. Sedangkan strategi marketing mix ini merupakan bagian dari strategi pemasaran, dan berfungsi sebagai pedoman dalam menggunakan unsure-unsur pemasaran yang dapat dikendalikan pimpinan perusahaan, untuk mencapai tujuan perusahaan dalam bidang pemasaran.

Adapun perbedaan pemasaran dan bauran pemasaran perlu diketahui bahwa pemasaran adalah kegiatan yang dilakukan untuk memenuhi kebutuhan dan keinginan dengan cara mempertukarkan produk dan nilai dengan individu atau kelompok yang

\footnotetext{
${ }^{28}$ Rambat Lupiyoadi dan A. Hamdani, manajemen Pemasaran Jasa, h 74
} 
lain. Sedangkan bauran pemasaran adalah sejumlah alat-alat pemasaran yang digunakan perusahaan untuk meyakinkan obyek pemasaran atau target yang dituju.

Dari pemaparan materi sebelumnya terdapat 4 komponen Marketing Mix. Menurut Philip Kotler "produk sebagai sesuatu yang dapat ditawarkan ke pasar untuk mendaptkan perhatian untuk dibeli, untuk digunakan atau dikonsumsiyang dapat memenuhi keinginan dan kebutuhan“.

Dalam praktiknya produk terdiri dari dua jenis yaitu yang berkaitan dengan fisik atau benda berwujud dan tidak berwujud. Benda berwujud merupakan produk yang dapat dilihat, diraba, atau dirasakan. Contohnya buku, meja, kursi, rumah, mobil dll. Sedangkan produk yang tidak berwujud biasanya disebut jasa. Jasa dapat disediakan dalam berbagai wahana seperti pribadi, tempat, kegiatan, organisasi dan ide-ide. ${ }^{29}$

\subsection{Konsep Strategi Pemasaran Dalam Islam}

Konsep pemasaran syariah sendiri sebenarnya tidak berbeda jauh dari pemasaran yang kita kenal. Konsep pemasaran yang kita kenal sekarang, pemasaran adalah sebuah ilmu dan seni yang mengarah pada proses penciptaan, penyampaian, dan pengkomunikasian values

\footnotetext{
${ }^{29}$ Kasmir, Manajemen Perbankan, (Jakarta: Raja Grafindo Persada, 2003)187
}

kepada para konsumen serta menjaga hubungan dengan para stekholder-nya.

Namun pemasaran sekarang menurut Hermawan juga ada sebuah kelirumologi yang diartikan sebagai untuk memujuk orang belanja sebanyak-banyaknya bedanya pemasar syariah mangajarkan pemasar agar jujur terhadap konsumen atau orang lain. Nilai-nilai syariah megajarkan pemasar agar tidak terperosok kepada kelirumologi itu tadi karena ada nilai-nilai yang harus dijunjung oleh seorang pemasar.

Pemasaran syariah bukan hanya pemasaran yang ditambahkan syariah karena ada nilai-nilai lebih pada pemasaran syariah saja, tetapi lebih jauhnya pemasaran dalam syariah, dan syariah berperan dalam pemasaran. Pemasaran berbasis syariah diartikan perusahaan yang berbasisi syariah diharapkan dapat bekerja dan bersikap professional dalam dunia bisnis, karena dengan profesionahlitas dapat menumbuhkan kepercayaan konsumen.

Syariah berperan dalam pemasaran bermakna satu pemahaman akan pentingnya nilai-nilai etika dan moralitas pada pemasaran, sehingga diharapkan perusahaan tidak serta merta menjalankan bisnisnya demi keuntungan pribadi saja ia juga harus berusaha menciptakan nilai-nilai keislah usaman dalam menjalankan usahanya.

Praktik bisnis dan pemasaran tengah mengalami pergeseran dan mengalami 
transformasi, dari level intelektual (rasional), ke emosional dan pada akhirnya ke level spritiual. Pada level intelektual, pemasar akan menyikapi pemasaran secara fungsional-teknikal dengan menggunakan sejumlah tools pemsaran, seperti segmentasi pasar, bauran pemasaran marketing mix targeting dan lain sebagainya.

Paradigma baru muncul dalam pemasaran, dilandasi oleh kebutuhan yang paling pokok, yang paling dasar, yaitu kejujuran, moral, dan etika dalam bisnis. Inilah spiritual marketing dalam hal ini menjadikan spiritual marketing merupakan tingkatan tertinggi dalam konsep pemasaran syariah. Spiritual marketing menjadi jiwa bagi bisnis berprinsipkan syariah. ${ }^{30}$

Seorang pengusaha dalam pandangan etika islam bukan sekedar mencari keuntungan, melainkan juga keberkahan, yaitu kemantapan dari usaha itu dengan memperoleh keuntungan yang wajar dan diridhoi oleh Allah SWT. Ini berarti yang harus diraih oleh seorang pedagang dalam melakukan bisnis tidak sebatas keuntungan materiil (bendawi), tetapi yang penting lagi aungadalah keuntungan immaterial (spiritual). ${ }^{31}$

\footnotetext{
${ }^{30}$ Kertajaya, Hermawan dan M. Syakir Sula. Syariah Marketing, (Bandung : Mizan 2006), h. 4-6

${ }^{31}$ Muhammad Djakfar, Etika Bisnis Islami Tataran Teoritis dan Praktis, (Jakarta : Selemba Empat, 2006), h. 86
}

Salah satu ciri khas pemasaran syariah adalah sifatnya yang religious. Jiwa seorang syariah markerter meyakini bahwa hukumhukum syari'at yang bersifat ketuhanan merupakan hukum yang paling adil, sehingga akan mematuhinya dalam setiap aktivitas pemasaran yang dilakukan. Dalam setiap langkah, aktivitas dan kegiatan yang dilakukan harus selalu menginduk kepada syariat Islam.

Seorang syariah marketer meskipun ia tidak mampu melihat Allah, ia akan selalu merasa bahwa Allah senantiasa mengawasinya. Sehingga ia akan mampu untuk menghindar dari segala macam perbuatan yang menyebabkan orang lain tertipu atas produk-produk yang dijualnya.

\section{METODOLOGY}

Jenis penelitian yang digunakan dalam penelitian ini adalah jenis penelitian deskriptif dengan pendekatan kualitatif. Penelitian deskriptif adalah suatu bentuk penelitian yang ditujukan untuk mendeskripsikan fenomena-fenomena yang ada, baik fenomena alamiah maupun fenomena buatan manusia, bisa berupa bentuk, aktivitas, karakteristik, perubahan, hubungan, kesamaan, dan perbedaan antara fenomena yang satu dengan fenomena 
lainnya ${ }^{32}$. Penelitian kualitatif adalah penelitian dengan beberapa karakteristik yaitu dilakukan pada kondisi alamiah, bersifat deskriptif, menekankan pada proses, analisis data secara induktif, serta lebih menekankan pada makna. ${ }^{33}$

Data dikumpul dengan menggunakan pendekatan observasi langsung kelapanagn, wawancara mendalam dengan pemilik perusahaan Tinta Kaili dan karyawannya. Setelah itu data diolah dengan melakukan reduksi data, penyajian data, dan pengecekan keabsahan data dengan melakukan verifikasi melalui proses trianggulasi metode dan data.

\section{HASIL DAN PEMBAHASAN}

\subsection{Gambaran Objek Penelitian}

Cikal bakal perusahaan ini berawal di tahun 1996 dimana pada saat itu 3 orang pelopor pendirinya yang masih berstatus sebagai mahasiswa memulai usaha kecilkecilan yang mana hanya bermodalkan nekat. Karena semua kebutuhan perlengkapan sablon hanya mengharapkan uang lebih dari biaya kuliah yang diberikan oleh orang tua.

Sablon stiker dan kaos merupakan 2 orderan yang sering dikerjakan, sedangkan

32 Nana Syaodih Sukmadinata, Metode Penelitian Pendidikan, (Bandung: PT Remaja Rosdakarya, 2006). 72

${ }^{33}$ Sugiyono, MetodePenelitianKuantitatif, Kualitatifdan $R \&$ \& , (Bandung: Alfabeta, 2011). 13 untuk spanduk masih menggunakan cara yang sangat tradisional, yaitu dengan membuat cetakan huruf yang kemudian diaplikasikan ke atas kain dengan cara membasahi gabus busa dengan cat, kemudian gabus busa yang sudah dibasahi cat tadi ditekan-tekan di atas cetakan huruf. Sehinga hasil cetakannya pun sangat jauh dari kata sempurna.

Seiring perjalanan waktu, pada tahun 2004 dengan melihat perkembangan kota Palu yang saat ini menjamurnya iklan-iklan atau publikasi terutama spanduk terpampang di jalan-jalan kota, sehingga memunculkan ide cemerlang dari ketiga pendirinya untuk membuat produk cetakan spanduk yang lebih sempurna. Sehingga akhirnya berujung pada ide mendirikan perusahaan yang berbadan hukum.Tepat pada tanggal 23 November 2004berdirilah CV. Tinta Kaili. ${ }^{34}$

Berdasarkan uraian diatas percetakan CV. Tinta Kaili sudah cukup lama menghasilkan karya nyata dari perusahaan yang bergerak dibidang percetakan. Dari pelopor usaha yang awal mulanya dikelola oleh 3 orang dengan kerja sama yang baik dengan tujuan memenuhi biaya pendidikan agar tidak bergantung lagi pada orang tua, mereka memulai usaha bersama dengan semangat dan kerja keras.

\footnotetext{
${ }^{34}$ Dokumen, Kantor Percetakan CV. Tinta Kaili, 15 Juli 2016
} 
Menurut informan yakni Pak Abdullah selaku Direktur CV. Tinta Kaili yang berhasil penulis wawancara di lokasi penelitian menceritakan mengenai sejarah maupun profil usaha ini bahwa :

" Percetakan ini awal mulanya hanya usaha sablon kecil-kecilan yang dilakukan pada saat itu kami masih duduk dibangku perkuliahan. Demi mencari penghasilan memenuhi biaya pendidikan, untuk meringankan beban orang tua. Dari proses sablon yang masih sangat sederhana dan hasilnya pun jauh dari kata sempurna. Bermodalkan nekat dan keberanian menjadi wirausaha kami tetap menggeluti perkerjaan ini dengan tekun dari awalnya hobi hingga menjadi rutinitas pekerjaan.

Perusahaan percetakan ini telah ada sejak 1996 berjalan seriring waktu para pendirinya pun melihat perkembangan yang semakin maju di Kota Palu, mereka berinisiatif untuk mendirikan perusahaan yang beradan hukum, tepatnya 23 November 2004 berdirilah CV. Tinta Kaili.

"perusahaan ini berstatus badan hukum yakni CV.Tinta Kaili. Perusahaan percetakan ini menawarkan produk dan jasa percetakan digital, berbagai bordiran, jahit, konveksi, baliho, spanduk, buku cetak, souvenir, banner, printer, kalender dan semua jenis cetakan lainnya. $" 35$

Perusahaan percetakan sama halnya dengan perusahaan di bidang-bidang lain yang mempunyai strategi yang mampu membuat kiprah peruasahaannya diminati di dunia pasar. CV. Tinta Kaili pun demikian peminatnya datang dari berbagai kalangan. Mulai dari pengguna kalangan berasala dari instansi, perorangan, partai, organisasi, sekolah maupun kampus. Penetapan harga dihitung berdasarkan nilai produksinya, diantaranya hitung modal, tenga kerja listrik dan lain-lainya kemudian dapat ditentukan margin dari suatu produk.

Produk dan jasa percetakan memiliki teknik promosi agar perusahaan mereka dikenal dan dapat bersaing secara sehat dengan perusahaan lain, aPromosi iklan mulai dri media cetak Koran social mediaa, banyaak juga langsung dari marketing dan direct selling. Percetakan yang mempunyai slogan "Rajanya Spanduk" hingga saat ini memiliki karyawan mancapai 48 orang. Mesin-mesin penunjang majunya industry ini dilengkapi 3 mesin digital printing, mesin offset, mesin ID Card, mesin sablon, mesin jahit manual dll. ${ }^{36}$

\subsection{Strategi Marketing Mix PT. Tinta Kaili}

Strategi marketing mix yang dilakukan oleh CV. Tinta Kaili dalam meningkatkan usahanya dengan menggunakan empat strategi marketing mix yang dilakukan dengan strategi produk, strategi harga, strategi tempat dan strategi promosi. Usaha

${ }^{36}$ Herman, Hasil Wawancara pada tanggal 15 Juli 2016 
percetakan kami memiliki cara atau strategi agar bias terus dikenal dan dimanfaatkan oleh khalayak. Masyarakat mengenal produk kami dan menjadi konsumen dari perusahaan kami.Olehnya banyak srategi yang kami terapkan hingga saat ini". ${ }^{37}$

\section{Product (Produk)}

Strategi produk dilakukan CV. Tinta Kaili menawarkan produk dan jasa di bidang percetakakan kepada konsumen / masyarakat Kota Palu melalui agen pemasarannya. Produk yang ditawarkan oleh perusahaan ini berupa berbagai jenis border, jahit konveksi, sablon. ${ }^{38}$ Produk yang pada Percetakan CV. Tinta Kaili diantaralain sebagai berikut:

Tabel 1. Produk PT. Tinta Kaili

\begin{tabular}{|l|l|l|}
\hline No & \multicolumn{1}{|c|}{ Jenis } & \multicolumn{1}{|c|}{ Ket } \\
\hline 1 & Bordir Komputer & $\begin{array}{l}\text { Kemeja, Jaket, Kaos, Logo, } \\
\text { Pataka, Topi, Handuk dll. }\end{array}$ \\
\hline 2 & Printing digital & $\begin{array}{l}\text { Cover baliho, Spanduk, X } \\
\text { Banner, Roll Banner, Sriker, } \\
\text { One Way vision }\end{array}$ \\
\hline 3 & $\begin{array}{l}\text { Percetakan Offset } \\
\text { Printing }\end{array}$ & $\begin{array}{l}\text { Poster, Brosur, Kalender, ID } \\
\text { Card }\end{array}$ \\
\hline 4 & Konveksi & $\begin{array}{l}\text { Offset Printing, Cutting Stiker, } \\
\text { Accessories }\end{array}$ \\
\hline
\end{tabular}

\section{Price (harga)}

Strategi penetapan harga dari suatu produk atau jasa yang dikerjakan ditentukan berdasarkan modal produksi, dari mulai bahan, jenis bordiran/ sablon, tenaga kerja, listrik bahan kaoskualitas jahitanwarna

\footnotetext{
${ }^{37}$ Abdullah, Direktur CV. Tinta Kaili .10 Agustus 2016

${ }^{38}$ Lian Officier CV. Tinta Kaili. 10 Agustus 2016
}

kaosgramasi kaosdesain jenis bahanjenis sablon jenis bodirproses produksiukuran/pola dan lama waktu pengerjaannya. memberikan potongan harga pada pelanggan yang sering memesan produk

\section{Place (Tempat)}

Strategi tempat, lokasi CV. Tinta Kaili berada di daerah yang cukup banyak penduduknya yang mempunyai peluang potensi pasar yang besar.juga berada di tempat keramaian letaknya di jejeran ruko di daerah pusat kota. Tempat tersebut merupakan lokasi yang tingkat kompetisinya rendah serta akses menuju ke tempat ini mudah dijangkau.Dari awal merintis pimpinan percetakan yakni Pak Abdullah telah menjalankan usaha mulai dari ngontrak hingga akhirnya memiliki lokasi sendiri, ada keinginan Pimpinan membuka cabang di daerah lain apabila nantinya dikemudian hari permintaan akan jasa percetakan miliknya sudah tersebar di berbagai daerah.

Adapun kendala yang dihadapi oleh CV. Tinta Kaili berkenaan dengan lokasinya di jl. Raja Moili yang mana perusahaan ini hanya memiliki tempat parkir yang sempit karena letaknya berada di pinggir jalan yang ramai melalui oleh kendaraan ,sehingga konsumen kesulitan untuk memarkirkan kendaraan ketika hendak mengunjungi perusahaan ini. 


\section{Promotion (Promosi)}

Strategi promosi yang dilakukan perusahaan agar tetap mempertahankan pelanggan serta menarik konsumen baru yang dilakukan percetakan CV. Tinta Kaili yakni :

a) Periklanan (Advertising), bentuk promosi non personal dengan menggunakan berbagai media yang ditujukan untuk mempengaruhi konsumen. Iklan yang mereka digunakan antara lain melalui media cetak maupun media elektronik.

b) Penjualan Tatap Muka (Personal Selling), bentuk promosi secara perorangan denganhanya melalui lisan dalam suatu pembicaraan dengan calon pembeli yang ditujukan untuk mempengaruhikonsumen.

c) Publisitas (Publisity), yaitu suatu bentuk promosi non personal mengenai, pelayanan atau kesatuan usaha tertentu dengan jalan mengulas informasi/berita tentangnya

d) Promosi Penjualan (Sales promotion), bentuk promosi diluar ketiga bentuk diatas yang ditujukan untuk merangsang pembelian. Seperti marketing perusahaan yang ditugaskan oleh pimpinan melalukan pengenalan dan kunjungan dimana konsumen bisa mengetahui lebih banyak produk dan jasa pada CV. Tinta Kaili ini.

$$
\text { "ya,, cukup banyak cara-cara yang }
$$
peusahaan kami lakukan demi kemajuan dan menigkatnya usaha ini, apalagi di zaman yang semakin maju didukung teknologi yang semakin canggih. Persaingan sehat antar perusahaan penting agar tetap eksis di hati konsumen". 39

\subsection{Marketing Mix dalam Perspektif}

\section{Ekonomi Islam}

Kegiatan pemasaran pada CV. Tinta Kaili berupa pelayanan barang dan jasa kepada konsumennya.marketing mix bauran pemasaran dari kegiatan percetakan ini berupa produk, harga, tempat, dan promosi. Merupakan unsur pemasaran yang harus tepat, dan rencana-rencana dari setiap unsur tersebut juga harus tepat. Bauran pemasaran merupakan variabel yang dapat dikendalikan oleh organisasi perusahaan untuk melakukan penyesuaian-penyesuaian terhadap target pasar atau mempengaruhi target pasar tersebut. organisasi perusahaan harus mengembangkan strategi-strategi dengan mengsinkronisasikan unsur-unsur bauran pemasaran untuk mencapai sasaran yang sama. $^{40}$

Syariah marketing merupakan suatu proses bisnis yang keseluruhan prosesnya menerapkan nilai-nilai Islam. Suatu cara bagaimana memasarkan suatu proses bisnis

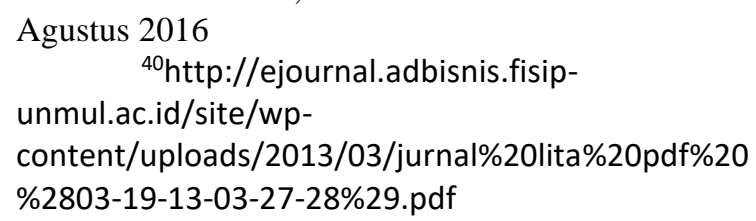


yang mengedepankan nilai-nilai yang mengagungkan keadilan dan kejujuran. Marketing sebagai sebuah disiplin bisnis strategis yang mengarahkan proses penciptaan, penawaran, dan perubahan values dari satu inisiator kepada stakeholders-nya.

Jadi, bagi kami syariah marketing adalah sebuah disiplin bisnis strategis yang mengarahkan proses penciptaan, penawaran, dan perubahan value dari suatu inisiator kepada stakeholders-nya, yang dalam keseluruhan prosesnya sesuai dengan akad dan prinsip-prinsip muamalah (bisnis) dalam Islam.

Dengan syariah marketing yang dilakukan CV Tinta Kaili, seluruh proses tidak boleh ada yang bertentangan dengan prinsip-prinsip yang Islami. Mulai dari sumber bahan, penjualan, distribusi dilakukan dengan aturan yang berdasarkan syariah.Dan selama proses bisnis ini dapat dijamin, atau tidak terjadi penyimpangan terhadap prinsip syariah, maka setiap transaksi apapun dalam pemasaran dapat diperbolehkan.

Dengan berpegang pada nilai-nilai yang terdapat pada Al-Quran dan Hadist, Nabi Muhammad melakukan bisnis secara profesional.Nilai-nilai tersebut menjadi suatu landasan yang dapat mengarahkan untuk tetap dalam koridor yang adil dan benar.Landasan atau aturan-aturan inilah yang menjadi suatu syariah atau hukum dalam melakukan suatu bisnis.Begitu pula penerapan percetakan ini pimpinan dan karyawan menjalankan usaha dengan kendali dan sesuai koridor dimana yang telah diatur.

Ada beberapa sifat yang membuat Nabi Muhammad berhasil dalam melakukan bisnis.Pertama adalah jujur atau benar.Dalam berdagang, Nabi Muhammad selalu dikenal sebagai seorang pemasar yang jujur dan benar dalam menginfromasikan produknya.Bila ada produknya yang memiliki kelemahan atau cacat, maka tanpa ditanyakan Nabi Muhammad langsung menyapaikannya dengan jujur dan benar.

Kedua, amanah atau dapat dipercaya.Seorang pebisnis haruslah dapat dipercaya seperti yang telah dicontohkan Nabi Muhammad dalam memegang amanah.Saat menjadi pedagang, Nabi Muhammad selalu mengembalikan hak milik atasannya, baik itu berupa hasil penjualan maupun sisa barang.

Sifat Nabi Muhammad ketiga adalah fathonah atau cerdas dan bijaksana.Dalam hal ini, pebisnis yang fathonah merupakan pemimpin yang mampu memahami, menghayati, dan mengenal tugas dan tanggung jawab bisnisnya dengan sangat baik.Dengan sifat ini, pebisnis dapat menumbuhkan kreativitas dan kemampuan dalam melakukan berbagai inovasi yang bermanfaat bagi perusahaan.Kita perlu 
menggunakan sifat ini agar bisa menjadi seorang pebisnis yang sukses.Dan keempat, Nabi Muhammad memiliki sifat tabligh atau argumentatif dan komunikatif.Bila anda seorang pemasar, maka anda harus mampu menyampaikan keunggulan-keunggulan produk dengan menarik dan tepat sasaran tanpa meninggalkan kejujuran dan kebenaran. ${ }^{41}$

Islam agama yang sangat luar biasa.Islam agama yang lengkap, yang berarti mengurusi semua hal dalam hidup manusia. Islam agama yang mampu menyeimbangkan dunia dan akhirat; antara hablum minallah (hubungan dengan Allah) dan hablum minannas (hubungan sesama manusia). Ajaran Islam lengkap karena Islam agama terakhir sehingga harus mampu memecahkan berbagai masalah besar manusia.

Islam menghalalkan umatnya berniaga. Bahkan Rasulullah Shallallahu 'alaihi wa sallam seorang saudagar - sangat terpandang pada zamannya. Sejak muda beliau dikenal sebagai pedagang jujur. "Sepanjang perjalanan sejarah, kaum Muslimin merupakan simbol sebuah amanah dan di bidang perdagangan, mereka berjalan di atas adab islamiah," ungkap Syekh Abdul Aziz bin Fathi as-Sayyid Nada dalam Ensiklopedi Adab Islam Menurut Alquran dan Assunnah.

\footnotetext{
${ }^{41}$ Ekis,

http://jurnalekis.blogspot.co.id/2008/08/syariahmarketing.html diakses 25 Juli 2016
}

Rasulullah Shallallahu 'alaihi wa sallam telah mengajarkan pada umatnya untuk berdagang dengan menjunjung tinggi etika keislaman. Dalam beraktivitas ekonomi, umat Islam dilarang melakukan tindakan bathil. Namun harus melakukan kegiatan ekonomi yang dilakukan saling ridho.

Berdagang penting dalam Islam. Begitu pentingnya, hingga Allah Subhanahu wa ta'ala menunjuk Muhammad sebagai seorang pedagang sangat sukses sebelum beliau diangkat menjadi nabi. Ini menunjukkan Allah Subhanahu wa ta'ala mengajarkan dengan kejujuran yang dilakukan oleh Muhammad bin Abdullah saat beliau menjadi pedagang bahwa dagangnya tidak merugi, namun malah menjadikan beliau pengusaha sukses. Oleh karena itu, umat Islam (khususnya pedagang) hendaknya mencontoh beliau saat beliau berdagang.

Dalam berdagang, pemasaran adalah disipilin bisnis strategi yang mengarahkan proses penciptaan, penawaran dan perubahan values dari satu inisiator kepada stakeholder-nya. Menurut prinsip syariah, kegiatan pemasaran harus dilandasi semangat beribadah kepada Tuhan Sang Maha Pencipta, berusaha semaksimal mungkin untuk kesejahteraan bersama, bukan untuk kepentingan golongan apalagi kepentingan sendiri. 
Al-Quran juga mengatur kegiatan kehidupan atau muamalah.Juga etika perdagangan, penjualan atau pemasaran.Salah satu ayat Al-Quran yang dipedomani sebagai etika marketing adalah QS.Al-Baqarah. Surat kedua dalam AlQuran ini terdiri atas 286 ayat, 6.221 kata dan 25.500 huruf, dan tergolong surat Madaniyah. Sebagian besar ayat dalam surat ini diturunkan pada permulaan hijrah, kecuali ayat 281 yang diturunkan di Mina saat peristiwa Haji Wada'. Surat ini yang terpanjang dalam $\underline{\mathrm{Al}-}$ Quran.Dinamakan Al-Baqarah yang artinya sapi betina karena di dalamnya terdapat kisah penyembelihan sapi betina yang diperintahkan $\underline{\text { Allah kepada Bani }}$ Israil (ayat 67-74). Surat ini juga dinamakan Fustatul Qur'an (Puncak AlQuran) karena memuat beberapa hukum yang tidak disebutkan dalam surat yang lain. Dinamakan juga surat Alif Lam Mim karena dimulai dengan huruf Arab Alif Lam dan Mim. Ayat 1-2 Al-Baqarah berarti: "Kitab ini (Al-Quran) tidak ada keraguan padanya; petunjuk bagi mereka yang bertakwa."

Ayat tersebut sangat relevan untuk dipedomani dalam pelaksanaan tugas marketing, sebab marketing merupaka $\mathrm{n}$ bagian sangat penting dari mesin perusahaan.Dari ayat tersebut dapat kita ketahui pula bahwa perusahaan harus dapat menjamin produknya.Jaminan yang dimaksud mencakup dua aspek - material, yaitu mutu bahan, mutu pengolahan, dan mutu penyajian; aspek non-material mencakup kehalalan dan keislaman dalam penyajian.

\section{PENUTUP}

Dari hasil penelitian yang dilakukan, penulis dapat menarik kesimpulan bahwasannya penerapan marketing mix yang ada di percetakan CV. Tinta Kaili memiliki peran terhadap meningkatnya usaha ini hingga berkembang dan maju, tetap eksis hinga saat ini dilihat dari usaha yang ada di perusahaan itu sendiri. Maka artinya penerapan marketing mix sangat berhasil dalamm embawa CV. Tinta Kaili kepada peningkatan usaha yang dimilikinya melalui 4p yaitu (Product) Produk, (Price) harga, (Promotion) promosi, dan (Place) tempat.

Kemajuan dan meningkatnya usaha percetakan ini tidak dapat dipungkiri juga bahwasannya usaha yang ada di CV. Tinta Kaili berhasil karena adanya penerapan nilainilai islami dalam menjalankan pekerjaan selama usaha ini dirintis serta tak luput perhatian seorang pemimpin dan kerjasama tim yang baik dalam bekerja.

\section{DAFTAR PUSTAKA}

Assauri, Sofjan. ManajemenPemasaran. Jakarta: RajawaliPers, 2014

Asyhadie, ZaeniHukumBisnis Jakarta: Rajawali Pers,2005 
HukumBisnis:

PrinsipdanPelaksanaannyadi

Indonesia. Jakarta: RajawaliPers, 2012.

Azis, Abdul, EtikaBisnisPerspektif Islam: ImplementasiEtikaIslamiUntukDunia Usaha, Bandung :Alfabeta, 2013

Christopher Pass \& Bryan Lowes, KamuslengkapEkonomiJakarta :Erlangga 1994

Departemen Agama RI, Mushaf Al-Quran Dan Terjemahnya

DepartemenPendidikanNasional ,Kamus Besar Bahasa Indonesia, Jakarta: Balai Pustaka, 2000

Dirman, http://skripsimanajemen.blogspot.co.id/search/lab el/Materi\%20Skripsi diunduh pada tanggal 23 november 2015

Ernie TisnawatiSule \& KurniawanSaefullah, Pengantar Manajemen Jakarta: Kencana, 2005

Fahmi, Irham. Kewirausahaan: Teori, Kasusdan Solusi. Bandung: Alfabeta, 2014

Harper, Boyd dkk, ManajemenPemasaran, Jakarta :Erlangga, 1997

J.Winardi, Enterpreneur dan entrepreneurship, Cet II; (Jakarta : Peradana Media, 2005,

Kasmirpemasaran Bank, edrevisi Jakarta, kencana, 2004

.KewirausahaanJakarta, Raja GrafindoPersada, 2006.

ManajemenPerbankan, Jakarta: Raja GrafindoPersada
Kertajaya, Hermawandan M. Syakir Sula.Syariah Marketing, Bandung: Mizan 2006

KhoirusSholeh, PenerapanStrategiMarketing Mix DalamMeningkatkan Usaha Kecil Dan Menengah Di Koperasi Trunojoyo Kabupaten Sampang Madura, Skripsi tidak diterbitkan, Jurusan Pendidikan IPS, UIN MAULANA MALIK IBRAHIM, Malang, 2010

KotlerPhilip dan Gary Amstrong, DasardasarPemasaran, Terjemahanoleh Alexander Sindoro, Jakarta :IndeksGramedia, 2003,.

Kotler,Philip Manajemen Pemasaran Analisis, perencanaan, implementasi dan pengendalian, alih bahasa Adi ZakariaAfif, VI.ke 1 Jakarta :Fakultas Ekonomi UI, 1993

.ManajemenPemasaran.Jakarta: PT. Rosdakarya 1993

Djakfar,MuhammadEtikaBisnisIslamiTatara $n$ Teoritisdan Praktis, Jakarta: SelembaEmpat, 2006

Yusant,Muhammad Ismaildan Muhammad Karebet Wijajakusuma, Mengagas Bisnis Islam. Jakarta: Gema Insane Press, 2002

MulyadiNitisusastro, Kewirausahan \& Manajemen Usaha Kecil. Bandung: Alfabeta, 2009

Munira,

http://skripsimanajemen.blogspot.co.i $\mathrm{d}$ /search/label/Materi\%20Skripsi diakses 23 nov2015

Mursid,M. ManajemenPemasaran, Jakarta:BumiAksara, 2014 
Rahma, "analisis pengaruh lokasi, produk, dan pelayanan pada pelanggan terhadap kepuasan konsumen pada percetakan CV. WatyGrafika Medan.”.blogspot.repository.usu.ac.i d(on-line).(23 Desember 2015)

RambatLupiyoadidan A. Hamdani, Manajemen PemasaranJasa, Jakarta :Selemba Empat, 2006

Riyanti, Benedicta Prihatin Dwi. Kewirausahaan : Dari Sudut Pandang Psikologi Kepribadian. Jakarta: Grasindo, 2003

Rizal, $\quad$ http://pengertianisp.blogspot.com/2015/05/pengertian -marketing-mix-marketingpemasaran.html (on-line) diakses pada tanggal 23 November 15

Rizka Fitriani Putri "Analisis Pengadaan Persediaan Bahan Baku Kertas Dalam Menunjang Proses Produksi pada CV. SumberWarna Bandung". Blogspot.repository.widyatama.ac.id. Diunduh 24 Desember 2015

Sakina, Pengaruh Bauran Pemasaran Terhadap Keputusan Membeli Kartu Prabayar Keputusan Membeli Kartu Prabayar Produk Telkomsel Pada Mahasiswa IAIN Palu, Skripsi tidak diterbitkan, JurusanEkonomi Islam, IAIN Palu, 2015.
Sugiyono, MetodePenelitianKuantitatif, Kualitatifdan $R \quad \& \quad D$, Bandung: Alfabeta, 2011.

Sukmadinata,NanaSyaodihMetodePenelitian Pendidikan, Bandung: PT RemajaRosdakarya, 2006.

Sunyoto,DanangStrategiPemasaran Jakarta: BukuSeru, 2015

Swasta,BasuManajemenPemasaran Modern. Jakarta : Liberty,2000

Tika Noor Afifah, Strategi Marketing Mix DalamMengokohkan Brand Image StudiDeskriptifKualitatifpadaRestora nOmahDhuwur di Kotagede Yogyakarta" (kripsitidakditerbitkan, JurusanIlmuKomunikasi,UINSunanK alijaga, Yogyakarta, 2013

TjiptonoFandi, StrategiPemasaran, Yogyakarta : ANDI, 1995

William ,Satanton, J., Fundamental of Marketing, terjemahan Y. Lamanto. Jakarta : PT. Erlangga, 1996

Networkbizid, SejarahPercetakan Digital.http://www.network.biz.id/20 13/inilah-sejarah-cetak-digitaldigital-printing (25 Juli 2016) 